\title{
Multippel sklerose - en mitokondriemediert sykdom?
}

\begin{abstract}
BAKGRUNN Mitokondrier spiller en viktig rolle i patogenesen ved ulike nevrodegenerative lidelser, som for eksempel Parkinson sykdom. Nevrodegenerative forandringer forekommer tidlig i forløpet av multippel sklerose (MS). Formålet med denne artikkelen er å presentere kunnskap om mulig sammenheng mellom mitokondriedysfunksjon og multippel sklerose.
\end{abstract}

KUNNSKAPSGRUNNLAG Artikkelen er basert på original- og oversiktsartikler valgt ut etter et litteratursøk i PubMed, begrenset til engelskspråklige artikler og avsluttet i mai 2016. Litteratursøket resulterte i totalt 2276 artikler. Etter en skjønnsmessig vurdering ble 71 artikler lest $\mathrm{i}$ sin helhet. Av disse ble 19 brukt som referanser. I tillegg plukket vi ut 15 artikler fra referanselistene og syv fra eget litteraturarkiv.

RESULTATER Mitokondrieforandringer er påvist i affiserte hjerneområder hos pasienter med multippel sklerose. Mens noen av forandringene kan skyldes skade på mitokondrier sekundært til inflammasjon, kan andre være kompensatoriske grunnet økt energikrav i aksoner som er rammet av demyelinisering. Type mitokondrieskade varierer og avhenger av utløsende skade.

FORTOLKNING Mitokondrieskade sekundært til inflammasjon kombinert med økt energikrav sekundært til demyelinisering kan føre til en kronisk energimangel i sentralnervesystemet. Dette kan igjen føre til nevrodegenerasjon. Økt kunnskap om mitokondrienes rolle ved multippel sklerose, både sekundært til inflammasjon og eventuelt som et direkte bidrag til nevrodegenerasjon, kan gi bedre forståelse for patogenesen ved sykdommen og kanskje bidra til nye behandlingsmuligheter.

Multippel sklerose (MS) er en immunmediert inflammatorisk sykdom i sentralnervesystemet karakterisert av demyelinisering og aksonal degenerasjon. Sykdommen preges av bortfallssymptomer forårsaket av nedsatt ledningsevne $\mathrm{i}$ aksonene grunnet demyelinisering.

Klinisk skiller man i hovedsak mellom pasienter med attakkvise nevrologiske symptomer, som over tid kan konvertere til en progredierende form (sekundær progredierende multippel sklerose), og en sannsynlig mindre andel som allerede ved debuttidspunktet utvikler progredierende symptomer (primær progredierende multippel sklerose). Ved attakkvis sykdom går symptomene helt eller delvis tilbake, mens den progredierende fasen er karakterisert av gradvis symptomforverring.

Årsakene til multippel sklerose er sannsynligvis en kombinasjon av multiple miljøfaktorer og genetisk sårbarhet (1). Inflammasjonens sentrale rolle i patogenesen er bekreftet gjennom autopsier, radiologiske funn og spinalvæskefunn (2). Imidlertid kan ikke inflammasjon alene forklare hele sykdomsutviklingen, som for eksempel det heterogene forløpet. Nevrodegenerative forandringer finnes $i$ alle stadier av multippel sklerose og kan også påvises i et tidlig sykdomsstadium, noe som tyder på at nevrodegenerasjon ikke nødvendigvis oppstår kun som en følge av inflammasjon (3).
Mitokondrier (fig 1) er intracellulære organeller med flere funksjoner, hvorav den viktigste er å produsere energi til cellene. Energibehovet i sentralnervesystemet er stort, og rundt $20 \%$ av kroppens oksygen som inngår i energiomsettingsprosessen, brukes av hjernen (4). Dette medfører en stor mitokondriepopulasjon, samtidig som det bidrar til å gjøre sentralnervesystemet særlig utsatt for mitokondriedysfunksjon.

Mitokondriesykdommer er blant de hyppigste arvelige metabolske sykdommer, og mange av disse rammer hjernen $(5,6)$. I tillegg spiller mitokondrier en viktig rolle ved nevrodegenerative tilstander, som for eksempel Parkinsons sykdom (7). Mitokondrienes rolle i utvikling av sykdommer som primært forårsakes av andre patologiske mekanismer, som for eksempel inflammasjon (4), er ennå ikke fullstendig klarlagt, men forskning antyder at mitokondriene spiller en rolle også her. Formålet med denne artikkelen var å se nærmere på sammenhengen mellom multippel sklerose og mitokondriefunksjon.

\section{Kunnskapsgrunnlag}

Artikkelen er basert på litteratursøk via PubMed. Søkeordene [multiple sclerosis] og/ eller [mitochondria] ble benyttet i følgende kombinasjoner: [multiple sclerosis] AND [mitochondria], [multiple sclerosis] AND [mitochondria] AND [pathogenesis], [mito-
Kristin N. Varhaug

kristin.nielsen.varhaug@helse-bergen.no

Christian A. Vedeler

Charalampos Tzoulis Laurence A. Bindoff

Klinisk institutt 1

Universitetet i Bergen

og

Nevrologisk avdeling

Haukeland universitetssykehus

\section{HOVEDBUDSKAP}

Patogenesen bak multippel sklerose er delvis ukjent, men innebærer både inflammasjon og nevrodegenerasjon

Mitokondrienes funksjon påvirkes av inflammasjon og demyelinisering ved multippel sklerose

Mitokondriedysfunksjon kan bidra til nevrodegenerasjon ved multippel sklerose 
chondria] AND [neurodegeneration] AND [demyelination], [multiple sclerosis] AND [oxidative damage], [multiple sclerosis] AND [axonal transport], [mitochondria] AND [fission fusion], [mitochondria] AND [DAMPs PAMPs].

Søket ble gjennomført uten tidsavgrensning og avsluttet i mai 2016. Både originalartikler og oversiktsartikler ble tatt med i vurderingen. Søket ble begrenset til engelskspråklige artikler. Litteratursøket resulterte i totalt 2276 artikler. Artiklenes relevans ble i første omgang vurdert på bakgrunn av tittel, og artikler hvor ikke mitokondrier eller multippel sklerose, nevrodegenerasjon eller demyelinisering var et tema ble ekskludert.

Etter eksklusjonen satt vi igjen med 194 artikler. Dernest ble sammendragene vurdert med henblikk på faglig relevans. 71 artikler ble lest $\mathrm{i}$ sin helhet, og av disse ble 19 brukt som refereanseartikler. 15 originalartikler ble plukket ut fra referanselisten til noen av de 71 artiklene som ble vurdert som relevante. I tillegg ble syv artikler hentet fra eget litteraturarkiv. Artiklene ble selektert ut fra vitenskapelig verdi og relevans.

\section{Multippel sklerose og mitokondrieforandringer}

Mitokondrieforandringer og mitokondriedysfunksjon er påvist i multippel skleroselesjoner både hos mennesker (i obduksjonsmaterialer) og i dyremodeller. Siden svikt i mitokondriefunksjon kan være både årsak til og konsekvens av sykdomsutvikling, er det viktig å forstå mitokondrienes rolle ved multippel sklerose - i tilfelle kunnskapen kan gi oss bedre forståelse av sykdomsmekanismen eller åpne for nye behandlingsmuligheter (8).

I det følgende gis en oversikt over ulik kunnskap om og hypoteser omkring mitokondrienes involvering ved multippel sklerose.

\section{Gir inflammasjon mitokondrieskader?}

Frie radikaler er molekyler med et uparet elektron som kan «stjele» elektroner fra andre molekyler i det som kalles en oksideringsreaksjon (9). Frie radikaler og andre reaktive oksygenforbindelser dannes som avfallsprodukter fra mitokondrienes energiproduksjon, men i tillegg dannes frie radikaler av aktiverte gliaceller og ved fagocytose, som en del av inflammasjonsprosessen.

Celler har utviklet flere typer beskyttelsesmekanismer mot frie radikaler og vil normalt kunne håndtere og nøytraliserer disse skadelige molekylene. Når cellene ikke lenger klarer å opprettholde sine antioksidative evner, oppstår den situasjonen som kalles «oksidativt stress». Oksidativt stress antas videre å føre til celleskade (9-11).

Inflammasjon er en viktig komponent $\mathrm{i}$

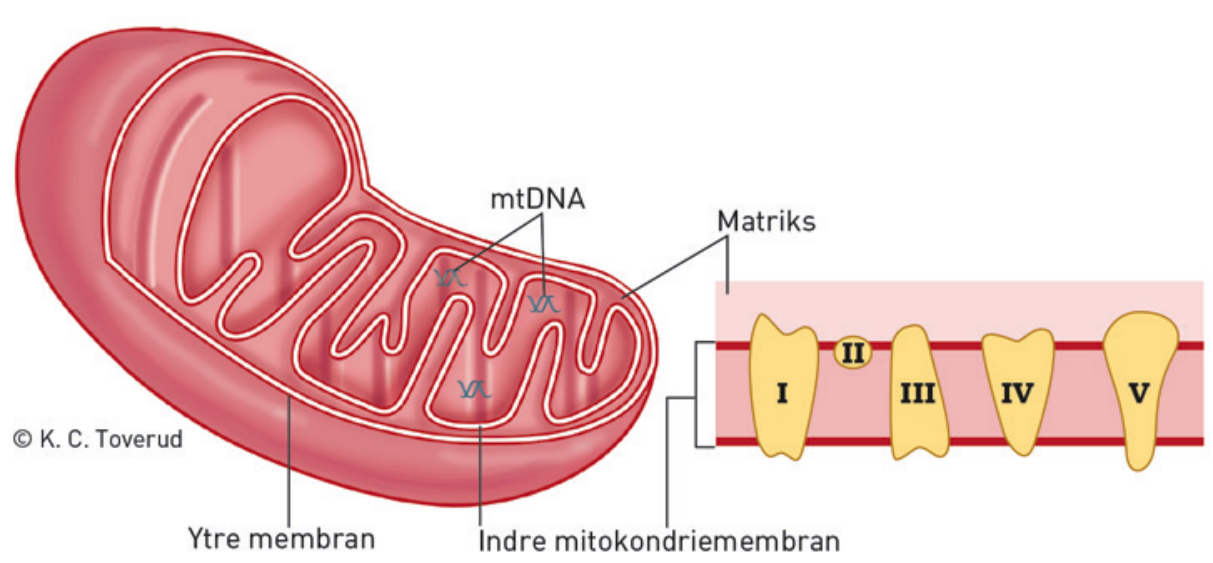

Figur 1 Mitokondriene er intracellulære organeller med dobbeltmembran og eget DNA Imitokondrie-DNA, mtDNA). Mitokondriene inneholder enzymer som deltar i flere prosesser, blant annet metabolisme av fettsyrer. glukose, steroider og aminosyrer og i programmert celledød (apoptose). Hovedfunksjonen er likevel å produsere energi. Denne prosessen heter oksidativ fosforylering, og enzymsystemet som gjennomfører prosessen heter respirasjonskjeden. Respirasjonskjeden er lokalisert i den indre mitokondriemembran og består av fem komplekser - kompleks I-V

patogenesen ved multippel sklerose. Siden det finnes aktive gliaceller i lesjonene, er det sannsynlig at produksjonen av reaktive oksygenforbindelser i multippel sklerose-lesjoner er økt. Dette underbygges av studier på autopsimateriale (12-14). I lesjonene er det påvist oksidativ skade, økt nivå av enzymer med antioksidativ evne og oppregulering av molekyler som er involvert i respiratorisk utbrudd og overaktivitet (respiratory burst).

Mitokondriene skades av reaktive oksygenforbindelser, og det er særlig kompleks IV i respirasjonskjeden (fig 1) som er utsatt. Nitrogenoksid konkurrerer med oksygen om binding til dette komplekset (15) og kan også ha en direkte inhibitorisk effekt (15-17). Det er også påvist tap av subenheter i kompleks IV i lesjoner som viser aktiv inflammasjon, med påfølgende redusert aktivitet av dette komplekset $(15,17)$.

I rottemodeller er det vist at slik inhibering skader, i tillegg til at det hemmer differensiering av celler som er nødvendige for remyelinisering (18). Ut fra funn av oksidativ skade og defekt kompleks IV i inflammatoriske multippel sklerose-lesjoner, mener man derfor at inflammasjon ved denne sykdommen kan gi sekundære mitokondrieskader (19).

\section{Gir demyelinisering mitokondrieforandringer?}

Mitokondriene er ikke statiske organeller, de beveger seg innad i alle celler. Det samme skjer i aksonene, hvor mitokondrier transporteres både ut fra cellekroppen langs aksonet og tilbake. Dette avspeiler endringen i lokalt behov for energi eller $\mathrm{Ca}^{++}$-regulering $(10,20,21)$.

Det er kjent at $\mathrm{Ca}^{++}$-nivået spiller en vik- tig rolle $\mathrm{i}$ de dynamiske forholdene innad $\mathrm{i}$ aksonet $(20,22)$. Svikt i $\mathrm{Na}^{+} / \mathrm{K}^{+}$-ATPaseaktivitet som følge av demyelinisering og økt $\mathrm{Na}^{+}$-konsentrasjon intraaksonalt kan videre reversere $\mathrm{Na}^{+} / \mathrm{Ca}^{++}$-pumpen og medføre opphopning av intraaksonalt $\mathrm{Ca}^{++}$(23). $\varnothing \mathrm{kt} \mathrm{Ca}^{++}$-konsentrasjon kan føre til nevronskade via enzymaktivering og hemming av mitokondriefunksjon, noe som kan føre til ytterligere økning i $\mathrm{Ca}^{++}$-influks (24).

Hos multippel sklerose-pasienter hvor $\mathrm{Ca}^{++}$-nivået $\mathrm{i}$ aksonet er forhøyet, vil $\mathrm{Ca}^{++}$økningen kunne hemme mitokondrietransporten, føre til akkumulasjon av mitokondrier på steder med oksidativt stress og videre gi mitokondrieskade $(25,26)$. Slik kan også demyelinisering gi sekundære mitokondrieskader.

Det er påvist økt tetthet av mitokondrier, økt utrykk av mitokondrieproteiner og økt aktivitet av kompleks IV i autopsimateriale fra etablerte multippel sklerose-lesjoner (27). Proteinet som låser mitokondriene til steder med økt energibehov er også økt i kronisk demyeliniserte aksoner (17), og lokaliseringen av proteinet samsvarer med lokaliseringen av økt mitokondriemasse $(17,22)$.

Ved aksonal demyelinisering blir aksjonspotensialet ødelagt. Som en antatt kompensasjon skjer det økt produksjon og endret distribusjon av $\mathrm{Na}^{+}$-kanaler, som ikke lenger blir forbeholdt Ranviers knuter, men spres diffust langs aksonet (23). Dette er en energikrevende prosess som kan forklare økt mitokondriemasse i aksonene (22).

Økning i mitokondriemasse og økt aktivitet tyder på kompensasjonsforsøk, muligens fordi tilstrekkelig energiproduksjon til en viss grad kan kompensere for effekten av demyelinisering. I tillegg er det en kompen- 
sasjonsrespons grunnet endret $\mathrm{Ca}^{++}$-nivå. Dessverre er kompensasjonsmekanismene ofte ikke tilstrekkelige, og på et tidspunkt vil sekundære skader på mitokondrier forekomme (28)

\section{Kan mitokondriedysfunksjon}

forklare nevrodegenerasjonen?

Som beskrevet over tyder altså forskning på at mitokondriedysfunksjon oppstår sekundært til inflammasjon og demyelinisering, samtidig som demyelinisering også initierer mitokondrielle kompensasjonsmekanismer. Balansen er kritisk.

Misforhold mellom energibehovet, som øker ved skaden, og nedsatt energiproduksjon, forbundet med mitokondriesvikt, vil til slutt resultere i kronisk energimangel, som igjen fører til aksonal degenerasjon, nevrondød og vevsnekrose $(24,29)$. I tillegg vil svikt $i$ transporten av mitokondrier langs aksonet forverre energisvikten og bidra til nevrodegenerasjon (30). Her vil for eksempel polymorfisme (sekvensendringer som ikke nødvendigvis er patogene) i gener som koder for transportproteiner, kunne spille en rolle og bidra til genetisk sårbarhet for multippel sklerose $(31,32)$.

Hva med den nevrodegenerasjonen som finnes ved multippel sklerose? Mitokondriene er unike, siden de er de eneste organeller med sitt eget DNA (mitokondrie-DNA, mtDNA). Det er påvist at mtDNA er syv ganger mer mottagelig for mutasjonsutvikling enn kjerne-DNA $(28,33)$, sannsynligvis grunnet mangel på beskyttende proteiner og dårlig reparasjonsevne, og det kan derfor bli direkte skadet av frie radikaler dannet ved for eksempel oksidativt stress.

Kronisk energimangel, mitokondriedysfunksjon og skadet mtDNA er kjennetegn ved nevrodegenerativ sykdom. Ved Parkinsons sykdom er høyt nivå av mtDNA-delesjoner (tap av en DNA-sekvens) i substantia nigra-nevroner og kompleks I-mangel (34) mistenkt for å være aktive og viktige komponenter i sykdomsmekanismen. Likeledes er det i kronisk aktive multippel skleroselesjoner også funnet økt skade på mtDNA, sammenlignet med «friske» områder (33).

Tilsvarende økning av mtDNA-delesjoner, som gir defekter i flere respirasjonskomplekser, er funnet hos pasienter med sekundær progredierende multippel sklerose, sammen med nevroner med manglende respiratoriske evner $(34,35)$.

Det er interessant at de mitokondrielle forandringene i etablerte multippel skleroselesjoner tilsvarer forandringer i klassiske mitokondriesykdommer som Kearns-Sayresyndrom og MERRF-sykdommen (myoklonisk epilepsi med ragged-red fibers) (36).

Forekomst av mitokondrieskader ved multippel sklerose antyder at mitokondrier spiller en rolle i nevrodegenerasjon som finnes ved denne sykdommen, men om mitokondrienes rolle er primær eller sekundær, er fortsatt ikke avklart.

\section{Diskusjon}

I flere studier med ulike innfallsvinkler konkluderes det med at mitokondriedysfunksjon oppstår sekundært til både inflammasjon og demyelinisering. Andre studier om multippel sklerose viser mitokondrieskader som ligner dem man finner ved Parkinsons sykdom, en antatt mitokondriebetinget nevrodegenerativ sykdom (7). Foreløpig er det ikke avklart om mitokondrieskader spiller en primær rolle i nevrodegenerasjonen som ses ved multippel sklerose, men spørsmålet vurderes som interessant.

Nåværende behandlinger bekrefter at inflammasjon er et viktig element i tidlig fase, især hos pasienter som debuterer med attakker. Men sykdommens heterogenitet hva gjelder behandlingsrespons og progrediering, og den tydelige og tidlige forekomsten av nevrodegenerasjon som ikke er en følge av inflammasjon (3), gjør at vi må se nærmere på andre mekanismer, inklusive mitokondrienes rolle.

Det er lansert to årsakshypoteser i forbindelse med patogenesen ved multippel sklerose: «utside-inn-hypotesen» og «innsideut-hypotesen» (8). Den første går ut på at inflammasjonen er et resultat av autoimmunitet med immunaktivering via faktorer fra det perifere immunsystemet som penetrerer blod-hjerne-barrieren (37). I «innside-uthypotesen» foreslås det at patologiske forhold innad i nevronene eller i omliggende hjernevev trigger en sekundær inflammasjonsrespons (19). I begge hypoteser kan mitokondriene teoretisk være involvert.

Det antas at mitokondriene stammer fra en bakterie - og mtDNA ligner på bakterielt DNA. I ulike studier er det funnet at mtDNA, eller deler av mtDNA, kan sette i gang sterile inflammatoriske responser gjennom det medfødte, ikke-spesifikke (innate) immunsystemet $(38,39)$. Videre er det påvist at eosinofile celler frigjør mtDNA. Dette skjer som ledd $\mathrm{i}$ et antibakterielt forsvar hvor mtDNA «fanger» bakterien som et bidrag til immunresponsen (40). Frigjøring av nevronalt mtDNA via en perifer inflammatorisk trigger kan derfor øke eller opprettholde inflammasjonsprosessen.

Alternativt kan akkumulering av skadet mtDNA, for eksempel grunnet oksidativ skade som ved multippel sklerose, frigjøres og medføre det samme (41). Ved en eventuell «innside-ut-mekanisme» kan man tenke seg en mer direkte mitokondriemediert mekanisme, hvor frigjort eller skadet nevronalt mtDNA faktisk er triggeren som igangsetter en immunrespons.

\section{Konklusjon}

Patogenesen bak multippel sklerose er kompleks, og forskjellige sykdomsmekanismer som inflammasjon og nevrodegenerasjon er involvert i patogenesen. Mitokondriedysfunksjon ser ut til å bidra til kompleksiteten. Økt forståelse av sykdomsmekanismer og mitokondrienes rolle kan være av betydning for fremtidige behandlingsmuligheter.

\section{Kristin N. Varhaug (f. 1983)}

er lege i spesialisering. Forfatter har fylt ut ICMJE-skjemaet og oppgir ingen interessekonflikter.

\section{Christian A. Vedeler (f. 1958)}

er overlege og professor i nevrologi.

Forfatter har fylt ut ICMJE-skjemaet og oppgir ingen interessekonflikter.

\section{Charalampos Tzoulis (f. 1979)}

er ph.d., spesialist i nevrologi og overlege. Forfatter har fylt ut ICMJE-skjemaet og oppgir ingen interessekonflikter.

\section{Laurence A. Bindoff (f. 1951)}

er professor i nevrologi overlege. Forfatter har fylt ut ICMJE-skjemaet og oppgir ingen interessekonflikter.

\section{Litteratur}

1. McKay KA, Jahanfar S, Duggan T et al. Factors associated with onset, relapses or progression in multiple sclerosis: A systematic review. Neurotoxicology 2016. E-publisert 1.4.2016.

2. Frischer JM, Bramow S, Dal-Bianco A et al. The relation between inflammation and neurodegeneration in multiple sclerosis brains. Brain 2009. 132: $1175-89$

3. Trapp BD, Peterson J, Ransohoff RM et al. Axona transection in the lesions of multiple sclerosis. N Engl J Med 1998: 338: 278-85.

4. Witte ME, Geurts JJG, de Vries HE et al. Mitochondrial dysfunction: a potential link between neuroinflammation and neurodegeneration? Mitochondrion 2010; 10: 411-8.

5. Gorman GS, Chinnery PF. DiMauro S et al. Mitochondrial diseases. Nat Rev Dis Primers 2016; 2: 16080

6. Lax NZ, Gorman GS, Turnbull DM. Invited Review: Central nervous system involvement in mitochondrial disease. Neuropathol Appl Neurobiol 2016. -Epublisert 11.6.2016.

7. Franco-Iborra S, Vila M, Perier C. The Parkinson Disease Mitochondrial Hypothesis: Where Are We at? Neuroscientist 2016: 22: 266-77.

8. Stys PK, Zamponi GW, van Minnen J et al. Will the real multiple sclerosis please stand up? Nat Rev Neurosci 2012; 13: 507-14.

9. Gilgun-Sherki Y, Melamed E, Offen D. The role of oxidative stress in the pathogenesis of multiple sclerosis: the need for effective antioxidant therapy. J Neurol 2004; 251: 261-8.

10. Sas K, Robotka H, Toldi J et al. Mitochondria, metabolic disturbances, oxidative stress and the kynurenine system, with focus on neurodegenerative disorders. J Neurol Sci 2007; 257: 221-39.

11. West AP, Shadel GS, Ghosh S. Mitochondria in innate immune responses. Nat Rev Immunol 2011; 11: 389-402

12. Lassmann H, van Horssen J. The molecular basis of neurodegeneration in multiple sclerosis. FEBS Lett 2011; 585: 3715-23. 
13. Haider L, Fischer MT, Frischer JM et al. Oxidative damage in multiple sclerosis lesions. Brain 2011; 134: 1914-24

14. van Horssen J, Schreibelt G, Drexhage J et al. Severe oxidative damage in multiple sclerosis lesions coincides with enhanced antioxidant enzyme expression. Free Radic Biol Med 2008; 45: $1729-37$

15. Mahad D, Ziabreva I, Lassmann $\mathrm{H}$ et al. Mitochondrial defects in acute multiple sclerosis lesions. Brain 2008; 131: 1722-35.

16. Carvalho KS. Mitochondrial dysfunction in demyelinating diseases. Semin Pediatr Neurol 2013; 20: $194-201$.

17. Mahad DJ, Ziabreva I, Campbell G et al. Mitochondrial changes within axons in multiple sclerosis. Brain 2009: 132: 1161-74.

18. Ziabreva I, Campbell G, Rist J et al. Injury and differentiation following inhibition of mitochondrial respiratory chain complex IV in rat oligodendrocytes. Glia 2010; 58: 1827-37.

19. Mahad DH, Trapp BD, Lassmann H. Pathological mechanisms in progressive multiple sclerosis Lancet Neurol 2015; 14: 183-93.

20. Birsa N, Norkett R, Higgs N et al. Mitochondrial trafficking in neurons and the role of the Miro family of GTPase proteins. Biochem Soc Trans 2013; 41: 1525-31

21. Youle RJ, van der Bliek AM. Mitochondrial fission, fusion, and stress. Science 2012; 337: 1062-5.

22. Kiryu-Seo S, Ohno N, Kidd GJ et al. Demyelination increases axonal stationary mitochondrial size and the speed of axonal mitochondrial transport. J Neurosci 2010; 30: 6658-66.

23. Craner MJ Newcombe J, Black JA et al. Molecular changes in neurons in multiple sclerosis: altered axonal expression of Nav1.2 and Nav1.6 sodium channels and $\mathrm{Na}+/ \mathrm{Ca} 2+$ exchanger. Proc Natl Acad Sci U S A 2004; 101: 8168-73.

24. Trapp BD, Stys PK. Virtual hypoxia and chronic necrosis of demyelinated axons in multiple sclerosis. Lancet Neurol 2009; 8: 280-91.

25. Forte M, Gold BG, Marracci $G$ et al. Cyclophilin D inactivation protects axons in experimental autoimmune encephalomyelitis, an animal model of multiple sclerosis. Proc Natl Acad Sci U S A 2007; 104: $7558-63$

26. Su KG, Banker G, Bourdette D et al. Axonal degeneration in multiple sclerosis: the mitochondrial hypothesis. Curr Neurol Neurosci Rep 2009; 9: 411-7.

27. Witte ME, BøL, Rodenburg RJ et al. Enhanced number and activity of mitochondria in multiple sclerosis lesions. J Pathol 2009. 219: 193-204.

28. van Horssen J, Witte ME, Ciccarelli O. The role of mitochondria in axonal degeneration and tissue repair in MS. Mult Scler 2012; 18: 1058-67.

29. Dutta R, McDonough J, Yin X et al. Mitochondrial dysfunction as a cause of axonal degeneration in multiple sclerosis patients. Ann Neurol 2006; 59: 478-89

30. Errea O, Moreno B, Gonzalez-Franquesa A et al. The disruption of mitochondrial axonal transport is an early event in neuroinflammation. J Neuroinflammation 2015; 12: 152.

31. Hares K, Kemp K, Rice C et al. Reduced axonal motor protein expression in non-lesional grey matter in multiple sclerosis. Mult Scler 2014; 20: 812-21

32. Hares K, Redondo J, Kemp K et al. Axonal motor protein KIF5A and associated cargo deficits in multiple sclerosis lesional and normal-appearing white matter. Neuropathol Appl Neurobiol 2016; n/a; Epub ahead of print
33. Lu F, Selak M, O'Connor J et al. Oxidative damage to mitochondrial DNA and activity of mitochondrial enzymes in chronic active lesions of multiple sclerosis. J Neurol Sci 2000; 177: 95-103.

34. Campbell GR, Worrall JT, Mahad DJ. The central role of mitochondria in axonal degeneration in multiple sclerosis. Mult Scler 2014; 20: 1806-13.

35. Campbell GR, Ziabreva I, Reeve AK et al. Mitochondrial DNA deletions and neurodegeneration in multiple sclerosis. Ann Neurol 2011; 69: 481-92.

36. Sparaco M, Schon EA, DiMauro S et al. Myoclonic epilepsy with ragged-red fibers (MERRF): an immunohistochemical study of the brain. Brain Pathol 1995; 5: 125-33.

37. Witte ME, Mahad DJ, Lassmann $\mathrm{H}$ et al. Mitochondrial dysfunction contributes to neurodegeneration in multiple sclerosis. Trends Mol Med 2014: 20: 179-87.

38. Krysko DV, Agostinis P, Krysko $O$ et al. Emerging role of damage-associated molecular patterns derived from mitochondria in inflammation. Trends Immunol 2011; 32: 157-64.

39. Zhang Q, Raoof M, Chen Y et al. Circulating mitochondrial DAMPs cause inflammatory responses to injury. Nature 2010; 464: 104-7.

40. Yousefi S, Gold JA, Andina N et al. Catapult-like release of mitochondrial DNA by eosinophils contributes to antibacterial defense. Nat Med 2008; 14: $949-53$.

41. Malik AN, Czajka A. Is mitochondrial DNA content a potential biomarker of mitochondrial dysfunction? Mitochondrion 2013; 13: 481-92.

Mottatt 3.3. 2016, første revisjon innsendt 13.6. 2016 godkjent 22.12. 2016. Redaktør: Ragnhild Ørstavik. 